\title{
Social-ecological resilience and biosphere-based sustainability science
}

\author{
Carl Folke $^{1,2}$, Reinette Biggs $^{1,3}$, Albert V. Norström ${ }^{1}$, Belinda Revers ${ }^{1}$ and $\underline{\text { Johan Rockström }}^{1}$
}

\begin{abstract}
Humanity has emerged as a major force in the operation of the biosphere. The focus is shifting from the environment as externality to the biosphere as precondition for social justice, economic development, and sustainability. In this article, we exemplify the intertwined nature of social-ecological systems and emphasize that they operate within, and as embedded parts of the biosphere and as such coevolve with and depend on it. We regard social-ecological systems as complex adaptive systems and use a social-ecological resilience approach as a lens to address and understand their dynamics. We raise the challenge of stewardship of development in concert with the biosphere for people in diverse contexts and places as critical for long-term sustainability and dignity in human relations. Biosphere stewardship is essential, in the globalized world of interactions with the Earth system, to sustain and enhance our lifesupporting environment for human well-being and future human development on Earth, hence, the need to reconnect development to the biosphere foundation and the need for a biosphere-based sustainability science.
\end{abstract}

Key Words: Anthropocene; biosphere stewardship; natural capital; resilience; social-ecological systems; sustainability science

\section{INTRODUCTION}

Work on the interplay between nature and society has a long history and deep legacies. This body of research has spanned work on local studies to global challenges, and encompasses diverse interpretations within, between, and across disciplines of the humanities, the social sciences, and the natural sciences. The concept of social-ecological systems is one interpretation to emerge from this history. Berkes and Folke (1998) started to use social-ecological systems as an integrated perspective of humansin-nature, and related it to the, at that time, emerging concept of resilience (Holling 1973, Folke 2006, 2016). Berkes and Folke (1998:4) pointed out that in the social-ecological systems perspective "the delineation between social and natural systems is artificial and arbitrary." In this concept the social refers to the human dimension in its diverse facets, including the economic, political, technological, and cultural, and the ecological to the thin layer of planet Earth where there is life, the biosphere. The biosphere is the global ecological system integrating all living beings and their relationships, humans and human actions included, as well as their dynamic interplay with the atmosphere, water cycle, biogeochemical cycles, and the dynamics of the Earth system as a whole. In this sense, the biosphere coevolves with the Earth system (e.g., Lenton 2016). Furthermore, the genetic and species diversity making up the biosphere allows it to persist and adapt under changing conditions thus making the Earth system more resilient to the rapidly rising speed and scale of socialecological change (Mace et al. 2014).

In essence, the social-ecological systems approach emphasizes that people, communities, economies, societies, cultures are embedded parts of the biosphere and shape it, from local to global scales. At the same time people, communities, economies, societies, cultures are shaped by, dependent on, and evolving with the biosphere (Clark and Munn 1986, Folke et al. 2011, Leach et al. 2012). Hence, people are not just interacting with but are inhabitants of the biosphere together with all other life on Earth, shaping its resilience in diverse ways, from the local to the global, consciously or unconsciously.
The major expansion of the human dimension into the Anthropocene (Vitousek et al. 1986, 1997, Steffen et al. 2007, Waters et al. 2016), the age of mankind, has resulted in a highly interconnected world with new cross-scale interactions linking people and places in new ways. These interactions are intertwined with and ultimately framed by the capacity of the biosphere as part of the complex dynamics of the Earth system to sustain progress and development (Odum 1989, Steffen et al. 2015a). The biosphere underpins our future by providing basic resources like food and water, through to influencing the spiritual, aesthetic, and cultural dimensions of our embeddedness in nature. This has become especially obvious in the Anthropocene era where humanity has accelerated into a big world on a small planet (Rockström and Klum 2015). In other words, humans are intertwined with the biosphere, and the emergence of the Anthropocene now suggests that humans have become a significant force in the dynamics of the Earth system at the planetary level (Steffen et al. 2007, Lenton 2016, Williams et al. 2015).

It should be clear that human development cannot be decoupled from the biosphere, as much as people think that human ingenuity and technology will allow this. Human well-being in all its dimensions, e.g., quality of life in terms of freedom and choice, good social relations, personal security, and material needs, ultimately rests on biosphere capacity and the interplay with the Earth system. Focusing primarily on wealth and inequality or social resilience while remaining ignorant about and disconnected from the biosphere and its stewardship is not a recipe for longterm sustainability for people on Earth.

In this article, we will clarify and exemplify the intertwined nature of social-ecological systems and emphasize that they operate as part of the biosphere and as such are dependent on it. We regard social-ecological systems as complex adaptive systems (Levin et al. 2013) and use a social-ecological resilience approach as a lens to address and understand their dynamics (Folke et al. 2010, Biggs et al. 2012, Folke 2016).

${ }^{1}$ Stockholm Resilience Centre, Stockholm University, Stockholm, Sweden, ${ }^{2}$ Beijer Institute, Royal Swedish Academy of Sciences, Stockholm,

Sweden, ${ }^{3}$ Centre for Complex Systems in Transition, University of Stellenbosch, South Africa 
As supporters of methodological pluralism (e.g., Norgaard 1989), we are not advocating a single specific platform or field as the only way to explain and understand the enormous challenges of the Anthropocene. Nonetheless, people and societies will continue to shape and be shaped by the biosphere and there is a growing imperative and recognition of the need for development approaches and global scientific endeavors that take account of the interdependencies between human well-being and the biosphere foundation, e.g., the Sustainable Development Goals, Future Earth. By adopting a social-ecological resilience approach, we bring a stronger focus on what development for human well-being entails in a biosphere context and in relation to sustainability, hence, the plea for a biosphere-based sustainability science. We raise the challenge of stewardship of human development in tune with the biosphere as critical for sustainable development and dignity in human affairs.

\section{SOCIAL-ECOLOGICAL SYSTEMS AND RESILIENCE}

Social-ecological resilience is the capacity to adapt or transform in the face of change in social-ecological systems, particularly unexpected change, in ways that continue to support human wellbeing (Chapin et al. 2010, Biggs et al. 2015). Adaptability refers to human actions that sustain, innovate, and improve development on current pathways, while transformability is about shifting development into new pathways and even creating novel ones (Walker et al. 2004, Folke et al. 2010). Shifting pathways or basins of attractions do not take place in a vacuum. Any transformation draws on resilience from multiple scales and diverse sources. It recombines experience and knowledge, learning with change, turning crises into windows of opportunity, and governing transformations for innovative pathways in tune with the resilience of the biosphere (Gunderson and Holling 2002, Westley et al. 2011). Resilience thinking explicitly focuses on understanding how periods of gradual change interplay with periods of rapid change in intertwined social-ecological systems confronted with true uncertainty and what that means for people and the planet.

Social-ecological systems are complex adaptive systems, where agents often interact in unplanned and unpredictable ways. These interactions underlie the emergence of broader scale patterns that feed back on the system and influence the interactions of the agents (Levin et al. 2013). Hence, the properties of complex adaptive systems change because of the interplay between the adaptive responses of the parts (or agents) and the emergent properties of the whole (Levin 1999, Lansing 2003). Causation is often nonlinear in complex adaptive systems with the potential for chaotic dynamics, multiple basins of attraction, and shifts between pathways or regimes, some of which may be irreversible. The dynamic interaction of variables of slow and fast change makes it difficult to know when such dramatic changes may occur and to pinpoint cause-and-effect mechanisms (Scheffer 2009, Rocha et al. 2015).

Success in controlling a narrow set of parameters may lead to surprising, and often adverse, outcomes in the broader system (Holling and Meffe 1996, Holling et al. 1998, Sterner et al. 2006, Cifdaloz et al. 2010). This tension is referred to as management and governance of specified resilience, that is, resilience to achieve a certain goal (Walker et al. 2009) at the expense and loss of general resilience (Carpenter et al. 2015). General resilience is the capacity of social-ecological systems to adapt or transform in response to unfamiliar, unexpected events and extreme shocks. It is a strategy for dealing with uncertainty and is especially relevant in the Anthropocene considering the rate and scale of change. Conditions that enable general resilience include diversity, modularity, openness, reserves, feedbacks, nestedness, monitoring, leadership, and trust (Carpenter et al. 2012).

Living with such complexity and uncertainty requires resiliencebuilding approaches to management and governance of socialecological systems (Folke et al. 2003). Recent work has proposed principles for building resilience in social-ecological systems in the face of change: (1) maintain diversity and redundancy; (2) manage connectivity; (3) manage slow variables and feedbacks; (4) foster complex adaptive systems thinking; (5) encourage learning; (6) broaden participation; and (7) promote polycentric governance. There are no panaceas for building resilience, and before applying such principles, careful consideration needs to be given to who may benefit or lose, to avoid entrenching or exacerbating existing inequalities (Biggs et al. 2015).

\section{HUMANITY AS PART OF THE BIOSPHERE: FROM EXTERNALITY TO PRECONDITION}

In the mid-1980s when the field of ecological economics emerged, it was often stated that ecologists pretended as if humans did not exist and economists as if nature did not exist (e.g., Costanza 1991, Costanza et al. 1997). There has been huge progress since then in realizing that people and nature are interdependent systems. But, conceptualizing this coupling and relating it to human well-being and sustainability may take different shapes.

Economics, for example, has conventionally emphasized three critical factors of production for economic development: land, labor, capital (Fig. 1A). The significance of land (agricultural land) as a scarce factor of economic production faded with the rise of fossil energy and the onset of the industrial revolution. Labor (all who participate in production by their mental and physical effort) and capital (money, tools, and machinery used to produce goods or services) became the limiting economic factors of production of the Great Acceleration (Steffen et al. 2015b). As a consequence, land, or the environment and the biosphere as a whole, was given less attention in strategies and measures of economic progress.

Ecological economists introduced the concept of natural capital as a way to broaden land to include energy, nonrenewable resources, ecosystems services, and the life-supporting ecosystems generating those (e.g., Costanza and Daly 1992, Jansson et al. 1994, Ekins et al. 2003, Kareiva et al. 2011). Labor and human capital were extended to social capital and even cultural capital to capture the role of governance and institutions and deeper societal values in human action (Berkes and Folke 1992, Baland and Platteau 1996, Dasgupta and Serageldin 1999, Pretty and Ward 2001, Putnam 2002). Capital was labeled human-made capital like technology and capital markets, and complementarity between the factors rather than substitutability was emphasized (e.g., Costanza and Daly 1992; Fig. 1B). 
Fig. 1. Factors of production of an economy. (A) The classical factors of production in economics, land, labor, and capital and (B) their extension into natural capital, human/social/ cultural capital, and human-made capital, emphasizing complementarity (e.g., Costanza and Daly 1992, Berkes and Folke 1992).
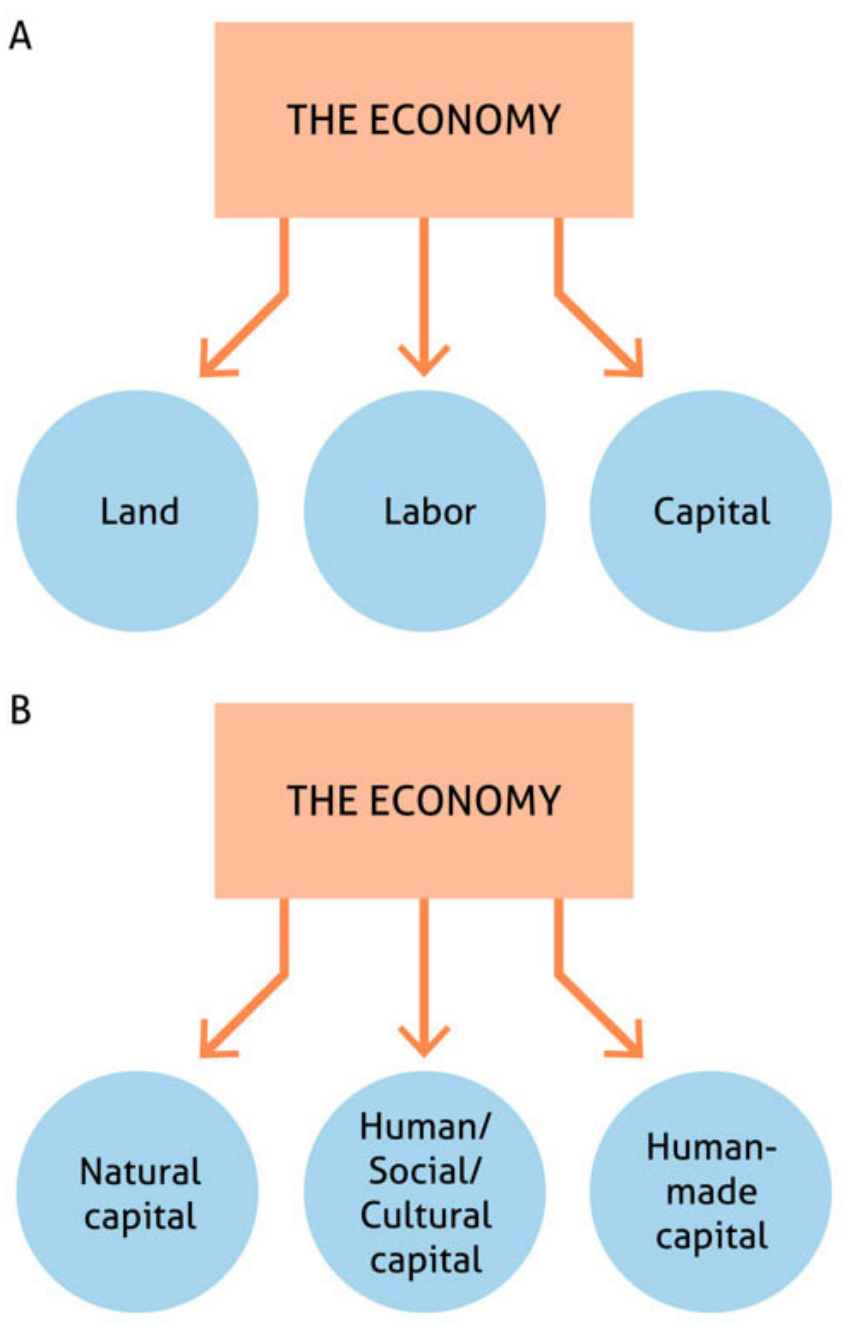

Currently, many attempts striving toward a green economy aim at making the significance of natural capital quantified and visible within the economy, as a key factor of production, i.e., internalizing significant dimensions of natural capital into economic development. Such efforts include carbon taxes, tradable permits, green accounting, inclusive wealth, or valuation of ecosystem services and natural capital.

The Brundtland report "Our Common Future" (WCED 1987) focused on three pillars of sustainable development: economic, social, and environmental. This model of sustainability has been widely used especially in the policy and business communities engaged with sustainable development (Fig. 2A). In this approach the three aspects or pillars are generally given equal weight and sometimes sustainability is attributed to one of them at a time, like environmental sustainability or sustainable economic growth.
Fig. 2. Conventional views of environment in development. (A) The three pillars of sustainability namely economy, society, and environment of the WCED (1987) and (B) five factors behind human well-being as often portrayed in the development sphere.
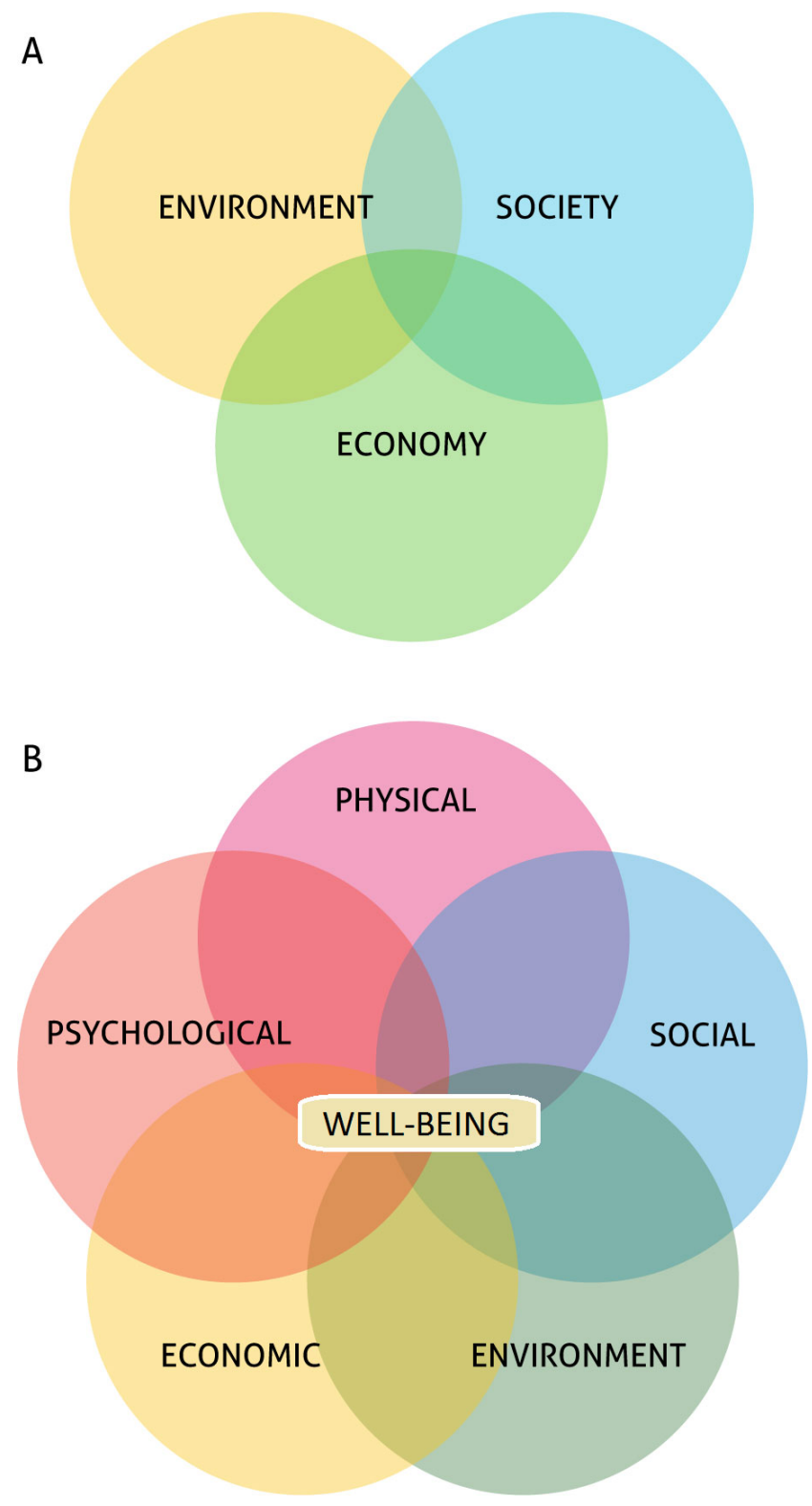

The broad field of development research has traditionally treated the environment as one among many factors contributing to human well-being (Fig. 2B). The tendency has been to focus on one natural resource at a time, on minimizing impacts on the environment, or appreciating a healthy environment. This way of relating humans to the environment was reflected in, e.g., the Millennium Development Goals. Many studies that argue for a deeper integration with the social sciences in social-ecological research still tend to approach environmental issues in this way. Here, the core focus is often on social dynamics and features linked 
to a certain environmental challenge (e.g., climate), a certain natural resource (e.g., fish stock, forest), or natural resource system (e.g., common-pool resource management).

The Millennium Ecosystem Assessment contributed to a current paradigm shift in the perspective of the human-nature relationship, from protecting the environment and conserving biodiversity to the challenge of stewardship of ecosystems and diversity and their services for human well-being. In this context, the provision of ecosystem services (Ehrlich and Mooney 1983, Costanza et al. 1989, Folke et al. 1991, de Groot 1992, Daily 1997) is critical for human well-being. It is generally recognized that biosphere capacity serves as the foundation for human well-being, that human well-being is embedded in and rests on a resilient biosphere (e.g., Folke et al. 2010). The Millennium Ecosystem Assessment played a significant role in fostering and mainstreaming such a social-ecological approach to humans and nature (e.g., Carpenter et al. 2009).

Such a perspective has a long legacy and was made explicit with, e.g., the development of ecological economics, drawing on work by scholars like Kenneth Boulding (1966), Eugene Odum (1989), Howard Odum (1971), and Herman Daly (1991). Here, it is explicit that the economy is a subsystem of society, in turn a subsystem of the biosphere (Fig. 3) and that the increase in scale and spread of the human dimension and the connectivity and speed of the globalized world now shapes the biosphere and our own future in profound ways (Daly and Cobb 1989, Costanza 1991, Folke 1991, Perrings et al. 1992, Folke et al. 2011, Steffen et al. 2015a). The biophysical basis and natural capital has always been a cornerstone in ecological economics, focusing on the interplay of scale, distribution and efficiency in this context.

Like ecological economics, the field of sustainability science (Kates et al. 2001, Komiyama and Takeuchi 2006, Bettencourt and Kaur 2011, Takeuchi et al. 2014) has emerged to inform and facilitate a transition toward sustainability, improving society's capacity to govern the earth in ways that simultaneously meet the needs of a much larger but stabilizing human population and substantially reduce hunger and poverty, while sustaining the lifesupport systems of the planet (Clark 2007, Matson et al. 2016).

The significance of the life-support systems and the biosphere as the foundation for the economy, society, and the human dimension as a whole has been the basis for the advancement of the planetary boundaries framework and in defining a safe operating space for humanity on Earth (Rockström et al. 2009, Steffen et al. 2015a). Here, the focus is on identifying and understanding the interactions and feedbacks among dynamic biophysical processes that regulate the Earth system, delineating the stability and resilience of the biosphere, and consequently its capacity in providing favorable conditions for complex human societies in the globalized world and for long-term human prosperity and even existence. The widely discussed, biophysically based, safe operating space framework has been combined with dimensions of the social foundation (e.g., Leach et al. 2012, Raworth 2012) and more recently in a biosphere context in relation to the Sustainable Development Goals (Griggs et al. 2013; Fig. 4).
Fig. 3. The economy and society as embedded within the biosphere, as intertwined parts of the planet. The biosphere serves as the foundation upon which prosperity and development ultimately rest. (A) based on C. Folke's lecture notes of early 1990s, (B) inspired by, e.g., Boulding (1966), Odum (1989), and Daly (1991), see also Folke (1991), Perrings et al. (1992).

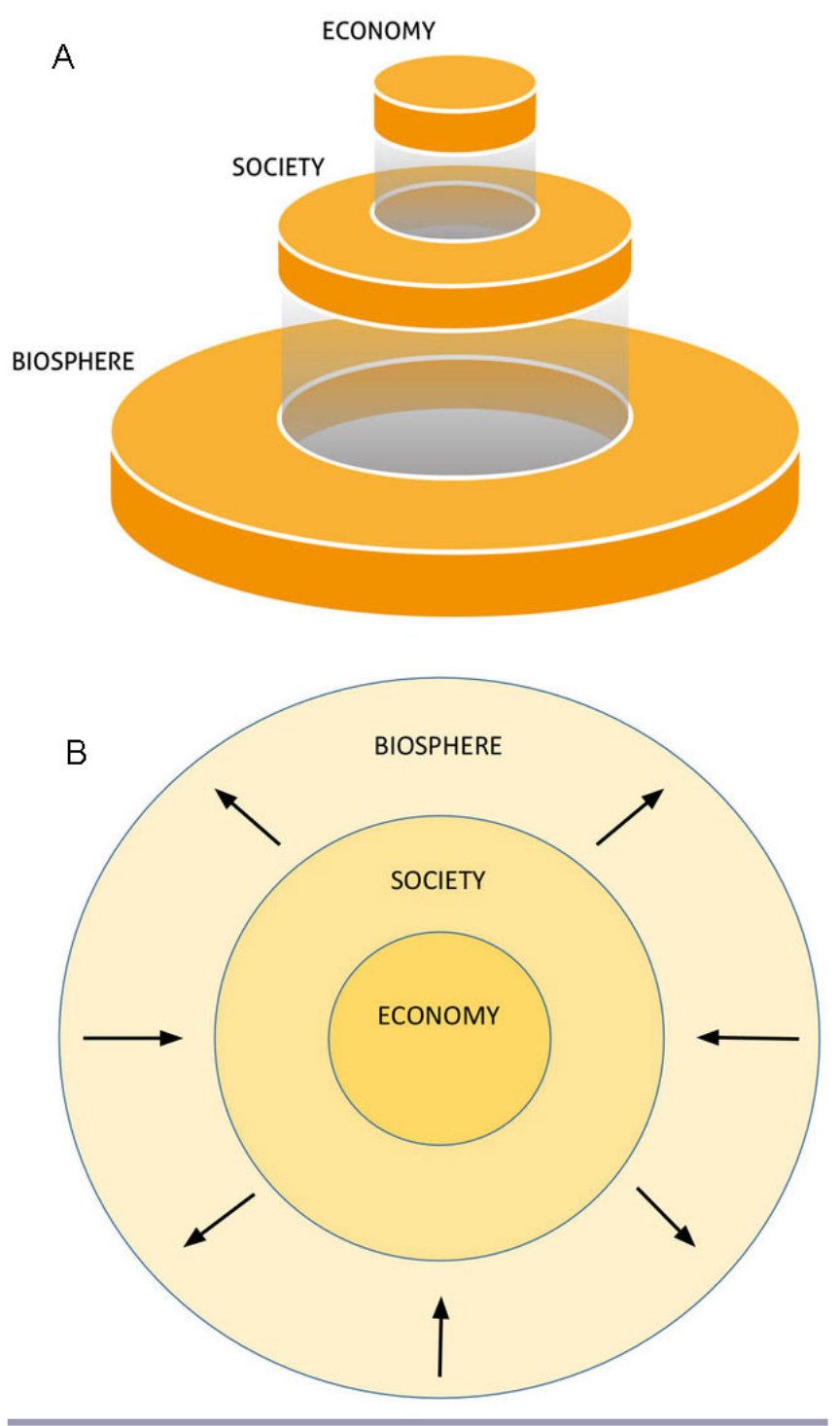

Work in ecological economics, sustainability science, socialecological systems, and resilience thinking are examples of the growing number of interdisciplinary and transdisciplinary platforms and arenas engaging deep competencies and commitments from scholars across the social sciences, humanities, and the natural sciences. There has been a lot of progress, with many new research fields emerging, interacting, and increasingly spilling over into conventional disciplines with diverse reactions and attitudes (e.g., Palsson et al. 2013, Brondizio et al. 2016). 
Fig. 4. The 17 Sustainable Development Goals positioned in relation to the biosphere foundation and the safe operating space for humans on Earth. Redrawn from Rockström and Sukhdev (2014) as presented at the 2016 EAT Forum (http://eatforum.org/event/eat-stockholm-food-forum-2016/\#program). The global goals logo and icons are from the Global Goals (http://www.globalgoals.org/\#the-goals), see also the Sustainable Development Knowledge Platform of United Nations (https://sustainabledevelopment.un. org/sdgs.

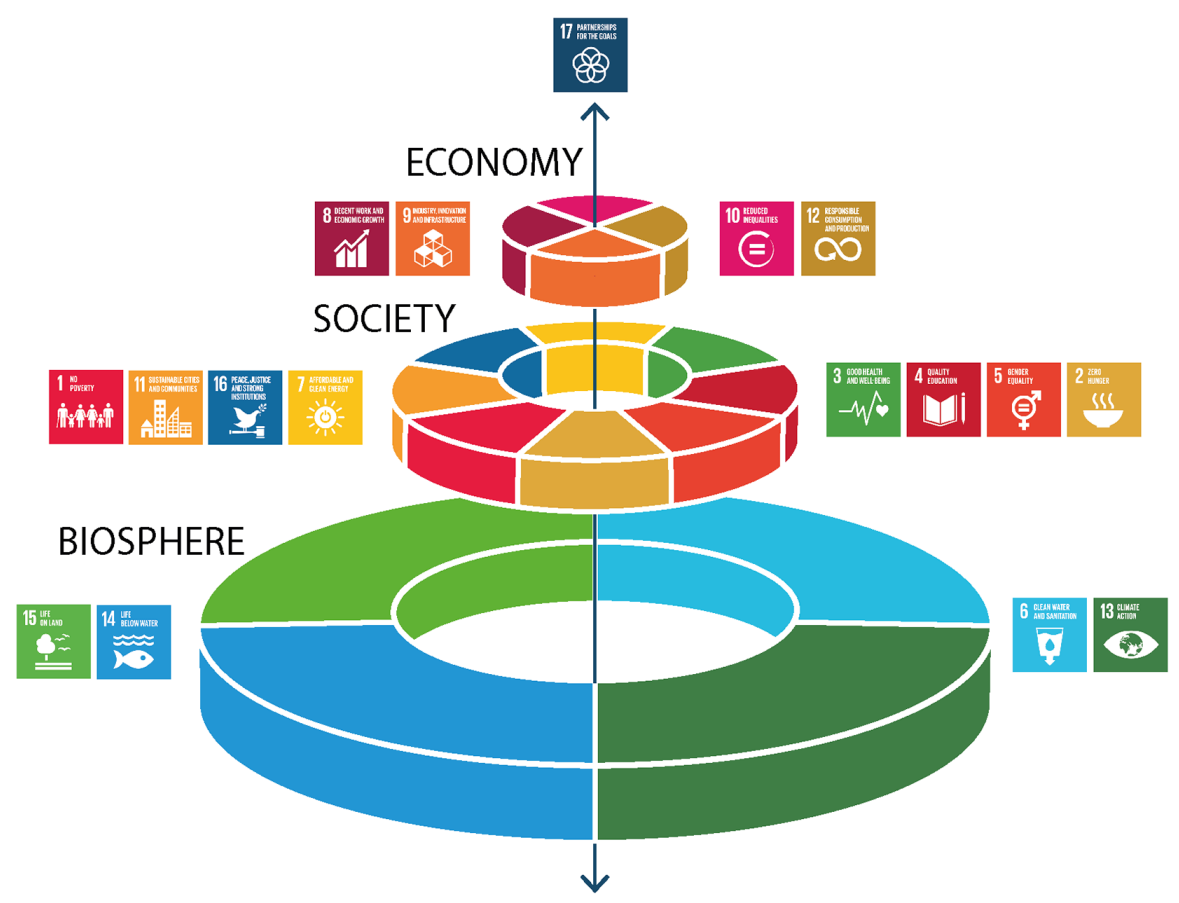

\section{THEGLOBAL GOALS}

For Sustainable Development
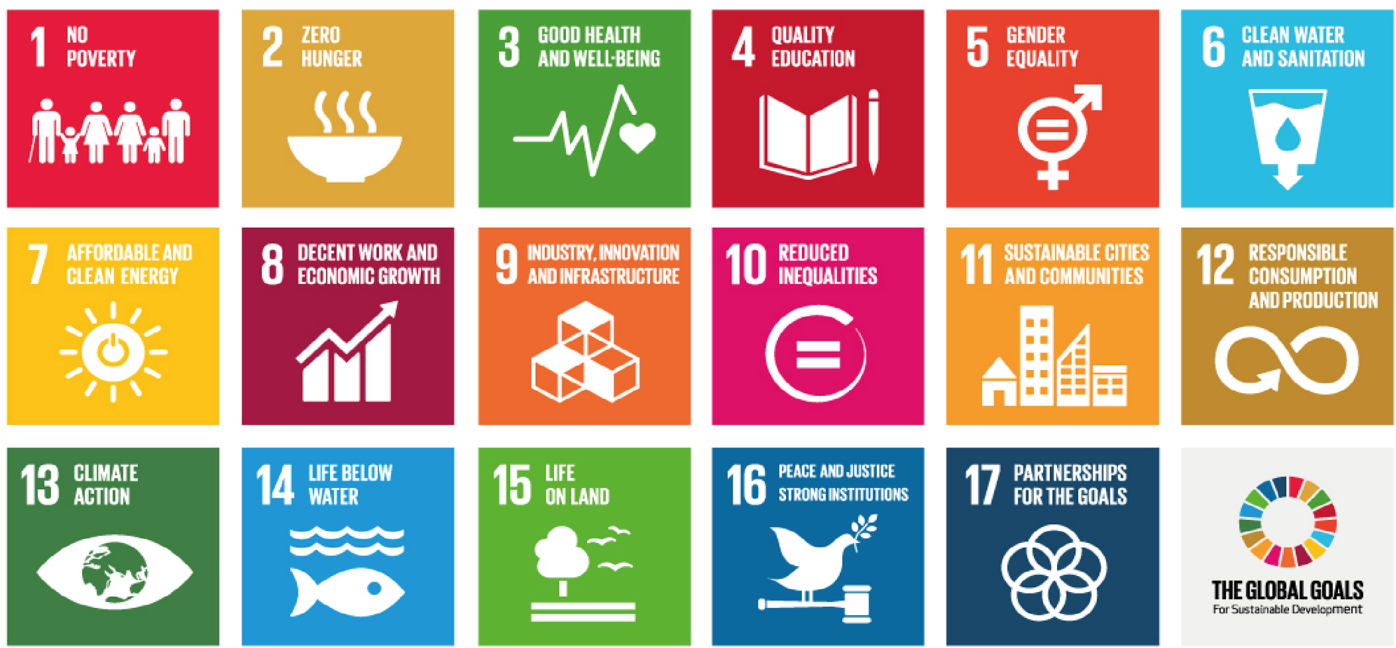

Several of those increasingly emphasize the significance of development in tune with the biosphere, of reconnecting development to the biospheric preconditions.

\section{INTERTWINED SOCIAL-ECOLOGICAL SYSTEMS}

It should be obvious that humans and our societies depend on resources and services of the biosphere. It should also be obvious that ecological processes and patterns can no longer be explained 
without considering the human influences in these (Turner et al. 1990, Levin 1999, Palumbi 2001, Ehrlich and Ehrlich 2008, Ellis 2015, Worm and Paine 2016). Clearly, the social and the ecological are linked in the form of coupled human-environment systems or coupled human and natural systems (Turner et al. 2003, Liu et al. 2007). If sustainability is the focus, these links are not just marginal, temporary, or loosely coupled. Rather, the social and ecological are intertwined, and in fact coevolving, shaping and being shaped by one another (Norgaard 1994, Berkes and Folke 1998). They interplay in complex ways with relations, interactions, and feedbacks that emerge across temporal and spatial levels and scales, often with unexpected outcomes and surprises (Walker et al. 2009, Homer-Dixon et al. 2015). As stated by Levin et al. (2013) macroscopic properties emerge from local actions that feed back and influence individuals' options and behaviors, but typically only do so diffusely and over much longer time scales.

If we are concerned beyond the present and with sustainability, the interplay of temporal and spatial scales of the social and the ecological, from history into the future, from local to global, clearly have to become part of the analysis (Schwartz 1991, Redman 1999, Costanza et al. 2012). In this sense, the coevolutionary development of people and nature as intertwined in the biosphere needs to be studied and not only within artificially established analytical borders but in the real globalized world of the Anthropocene (Kallis and Norgaard 2010, Williams et al. 2015, Lenton 2016). Humans operate in a legacy of socialecological interplay, directly or indirectly, consciously or unconsciously, shaping the capacity of the biosphere and our options and opportunities for development. This is a critical observation if sustainability for us humans, future generations included, is of concern. And if human well-being is a central goal of sustainability, its dependence on a resilient biosphere has to be accounted for, a necessity that has become more and more obvious.

\section{What reflects an intertwined social-ecological system?}

Here, we provide two examples, one from southern Madagascar and one from Maine, USA. In southern Madagascar, the agropastoralist landscape could be described as a seriously degraded environment. But surprisingly, when the resolution of maps of the region is enhanced small remnants of forests appear. A closer look at these forests on the ground reveals a rich biodiversity within them, with unique and endemic species of Madagascar, like lemurs. Madagascar holds some 50 species of lemurs, but through human actions over history the island has lost the bulk of its forest cover and many of its species. It turns out that the forest patches are instrumental for the remaining lemur species, serving as a network of suitable habitats connecting lemur life and movements (Bodin et al. 2006). Bees from hives in the forest patchwork pollinate the surrounding landscape and increase the yields of bean crops. The forest patches shelter fields from wind and sand and serve as primary habitats for many insects.

Clearly, such a forest patchwork of crucial refugia for many species has to be conserved and protected from human use and abuse. Ecologists would engage with international environmental NGOs and develop plans for protected area management to secure the rich diversity of the forests and the ecosystem services they generate. Discussions with decision-making bodies, nationally and internationally, would take place and conservation policies and practices would develop.

But, having a closer look at these forest remnants, extending the scope from the ecological to the social-ecological, reveals that these patches are sacred sites where ancestors of the local groups, the Tandroy of the Androy region, have been buried (Tengö et al. 2007). Tandroy moral order derives from the social imagination of powerful, widely shared ideas and norms of the clan, which in turn is based upon the ancestral land and ancestral laws, as recollected through story, song, and ritual, a cultural relation between dead and living members of clans, like a social-ancestral contract (von Heland and Folke 2014). Hence, these taboo forests are culturally protected and it is because of the social-ancestral contract that the forest patches, their diversity and ecosystem services critical to local livelihood and appreciated by people around the world, still persist. Clearly, neither the ecosystem nor culture alone delivers ecosystem services to society; the services emerge in their relations, consciously or unconsciously (Gadgil et al. 1993, von Heland and Folke 2014). It is a coevolved, intertwined social-ecological system.

The lobster fisheries of Maine is another telling case of an intertwined social-ecological systems. The fishery has been documented as a remarkable example of successful collective action and multilevel governance. In contrast to many other fisheries in the Gulf of Maine (USA and Canada), the lobster population has not been overexploited or collapsed and the governance of the Maine lobster fishery has succeeded in maximizing abundance and economic value of the lobster. The fishers, whose conservation ethic is aligned with maintaining lobster abundance, have worked collectively to minimize illegal actions and to preserve reproductive populations of lobsters (Acheson 2003).

The case of the Maine lobster has witnessed true success as a model for sustainable management of a heavily fished stock, a model of collective action in action, incorporating issues of power, conflict, and inequality. The lobster case is an iconic example of the ability of humans to collaborate, from the level of individual actors, to higher levels of governance and connected to global markets.

However, if the analysis is extended to an intertwined socialecological system a broader picture emerges. It turns out that centuries of intense fishing in the Gulf of Maine has removed lobster predators like groundfish (e.g., cod, haddock) to such an extent that their role in regulating lobster populations has disappeared. As a consequence, the lobster population has exploded, comparable to an insect outbreak, effectively leading to a vast lobster monoculture of the coastal waters of Maine (Steneck et al. 2011). Simplified ecosystems, like monocultures, are vulnerable to disturbance and may rapidly shift into alternative states in the face of shocks because of lack of resilience (Scheffer et al. 2001, Folke et al. 2004). In New England, south of Maine, there has been $>70 \%$ decline in lobster abundance due to a lethal shell disease related to increases in ocean temperature with links to climate change. If such mortality were to occur in Maine the coastal fishing villages would face serious challenges (Steneck et al. 2011). 
The Madagascar case reflects a social-ecological system in an explicit fashion: culture and nature are intertwined and coevolve. The Maine case reveals how "success" in the social domain may mask vulnerability across the broader social-ecological system. One may argue that the Maine case serves as a microcosm of the global situation facing humanity in the Anthropocene, where development paradigms have generally forgotten the significance of the biosphere for human well-being.

Although both cases are local they are also embedded within, dependent upon, and strongly influenced and shaped by crossscale interactions, both temporal and spatial. Despite a life in the arid and fluctuating landscape of southern Madagascar and their documented history of hardship and poverty, the Tandroy coevolved social-ecological system has displayed remarkable persistence. It seems like the ancestral contract has played a critical role in keeping the Tandroy together across generations, surviving recurring climatic shocks and guiding their history and culture (von Heland and Folke 2014). But the adaptations of the social-ecological system is challenged by climatic change and pressures of globalization (Tengö and von Heland 2012). The Maine lobster fishery is tied to global markets. The fragility became evident during a recent worldwide economic crisis, when consumer demand for lobsters rapidly declined and Canadian processors, central in international distribution of Maine lobsters, shut down because they were financed by insolvent Icelandic banks. Now, climatic change and disease challenge the simplified marine ecosystem of lobster aquaculture (Steneck et al. 2011).

\section{THE INTERTWINED SOCIAL-ECOLOGICAL ANTHROPOCENE}

During the past century, and especially since the 1950s, there has been an unprecedented expansion and acceleration of human activities and technological developments into a converging globalized society, to a large extent supported by fossil energy (McNeill 2000, Steffen et al. 2004, 2015b). Gaps between rich and poor countries have been closing and health and material standards of living for many people on Earth have improved (Rosling 2010). Despite vast inequalities within countries and a huge number of people still mired in deep poverty (Dasgupta 1995, Stiglitz 2012, Piketty 2014), the acceleration continues with a rise of an affluent middle class in a rapidly urbanizing world and with information technology, nano-technology, and molecular revolution accelerating with unknown potentials, challenges, and futures.

The scale, speed, spread, and connectivity of human actions in the Anthropocene generate new dynamics that connect previously unconnected domains (Walker et al. 2009, Biggs et al. 2011, Homer-Dixon et al. 2015, Bai et al. 2016) and can result in cascading effects across countries and regions (Holling 1995, Adger et al. 2009, Liu et al. 2013, Eriksson et al. 2015) affecting human well-being and transforming landscapes and seascapes (Berkes et al. 2006, Lambin and Meyfroidt 2011, Fairhead et al. 2012, Lazarus 2014). Local events can escalate into global challenges and local places are shaped by global dynamics (Galaz et al. 2011, Crona et al. 2015a,b). Societies and ecosystems are intertwined from local to global scales, making them socialecological systems.

Studies of local social-ecological systems of landscapes and seascapes ought to, therefore, not only focus on endogenous relations and challenges, but also account for and prepare for interacting with persistent and pervasive influences from other levels, be it economic drivers, technological change, transnational companies, migration issues, political decisions, belief systems, altered rainfall patterns, spread of disease, or climate change. Some of those may be abrupt and surprising and others may slowly alter the resilience of the social-ecological systems (Lenton et al. 2008, Hughes et al. 2013, Homer-Dixon et al. 2015).

An illustrative example of intertwined social-ecological dynamics across levels and scales is the rapid urbanization pattern of the Anthropocene. Almost $60 \%$ of the human population now lives in urban contexts and a large number of new cities are expected to be built. This escalating urban development presents great opportunities and also huge challenges, and not only within the social domain as manifested, e.g., in power relations, inequalities, and livelihood challenges in growing cities. The resource and ecosystem service needs of cities can rarely be sustained locally, but depend on extensive and often far-away biosphere support areas (Folke et al. 1997, Grimm et al. 2008). Irrespective of whether or not urban dwellers perceive themselves as part of and dependent on the biosphere, their behaviors and choices shape social-ecological landscapes and seascapes around the world through, e.g., markets, institutions, and global infrastructures (Seto et al. 2012, Andersson et al. 2014, Cumming et al. 2014). Such urban-biosphere interaction is prone to create or redistribute inequalities in social and economic power. Income inequalities play a role in the market selection of new products and power plays a central role in technological and institutional change (Kallis and Norgaard 2010, Safarzyńska and van den Bergh 2010). Hence, power and inequality of escalating urbanization in a telecoupled global society may drive rapid and widespread land use changes and thus play an important role in shaping the biosphere.

Another example is the globally expanding demand and trade for seafood shaping marine ecosystems worldwide through the increased harvest of wild capture fisheries and aquaculture production (Troell et al. 2014, Crona et al. 2015a). Today, nearly $40 \%$ of seafood enters international trade directly, and there is a substantial industry consolidation, with large and vertically integrated transnational corporations operating across entire supply chains from production through to retail (Österblom et al. 2015). This system of nested and cross-scale connections plays an important role in linking distant species and ecosystems to major markets and consumers. Such links can emerge rapidly and spread like contagious resource exploitation (Eriksson et al. 2015). At the same time such activities may cause cascading effects and regime shifts, with resulting system-wide changes in the marine ecosystems on which seafood production and human livelihoods depend (Nyström et al. 2012, Golden et al. 2016). The consequences of these intertwined social-ecological dynamics can also spread to terrestrial ecosystems; bushmeat hunting in West Africa, for example, has increased following the collapse of coastal fisheries caused by overfishing by international fleets (Brashares et al. 2004).

The Earth as transformed by human actions (Turner et al. 1990, Mora 2014, Williams et al. 2015) and the speed, spread, and connectivity of the Anthropocene epitomize contemporary not just linked but intertwined social-ecological systems (Young et al. 2006, Galaz et al. 2012, Helbing 2013). Social conditions, health, 
culture, democracy, power, justice, equality, matters of security, and even survival are interwoven with the global ecological system - the biosphere - in a complex interplay of local, regional, and worldwide dependencies. Although the perceived importance of ecosystems to people has perhaps decreased, and the proportion of people who extract goods directly from ecosystems is declining, the role of the biosphere in generating growth and prosperous development of the globalized human dimension remains fundamental. The continuous development of contemporary society requires an accommodating biosphere and favorable state of the Earth system (Steffen et al. 2011). We may rule the planet in many respects, but we still remain dependent on it.

\section{BIOSPHERE STEWARDSHIP}

The rapid changes of the Anthropocene have raised concerns of transgressing dynamic planetary boundaries raising the risks of crossing potential thresholds and tipping points at large scales, with shifts in feedbacks that may trigger irreversible and selfreinforcing dynamics and potentially even shift the Earth system into a different state (Lenton et al. 2008, Rockström et al. 2009, Steffen et al. 2015a). Such shifts would have pervasive implications for the future well-being and even survival of humanity on Earth. Now, incentives, institutions, and transformations are needed to redirect human behaviors and actions to explicitly become reconnected to the capacity of the biosphere to sustain the human dimension as well as stewardship of that capacity (Clark and Munn 1986, Chapin et al. 2009, Folke et al. 2011, Steffen et al. 2011, Leach et al. 2012, Galaz 2014). Sustainability requires improved stewardship of human actions in concert with the biosphere, from the local to the global and across scales, because the capacity of the biosphere serves as the foundation upon which the success of human future rests.

In general terms, stewardship is the careful and responsible management of something that you are responsible to care for. Stewardship, as we see it, is an adaptive process of responsibility to shepherd and safeguard the valuables of not just one self but also of others, a process that has potential to create meaning and build respect and dignity for the competencies and skills embedded with stewardship.

Stewardship theory is a framework that argues that people are intrinsically motivated to work for accomplishing the tasks and responsibilities with which they have been entrusted. Stewardship represents a relationship-centered collaboration that fosters trustworthy behavior (Davis et al. 1997). The theory places greater value on goal convergence among the parties involved than on the agent's self-interest (Van Slyke 2007, Hernandez 2012). Sociological and psychological approaches to stewardship theory depict managers as collectivists, pro-organizational, successfully performing inherently challenging work, exercising responsibility, and gaining recognition from peers for their work (Donaldson and Davis 1991).

In stewardship, managers tend to seek other ends besides financial ones, including a sense of worth, altruism, a good reputation, a job well done, a feeling of satisfaction, and a sense of purpose. Empirical studies of successful firms have proposed that the core of success can be explained by a pervasive ethic of collaboration, i.e., a system of moral principles and values grounded in a sense of joint stewardship that enables colleagues to achieve lofty individual and collective ambitions, and that helps them to learn and grow in a continuously self-sustaining way (Haskins et al. 1998). Stewardship theory provides one framework for characterizing the motivations of managerial behavior in various types of organizations (Menyah 2013).

Ecosystem stewardship has been presented as an action-oriented framework intended to foster social-ecological sustainability of a rapidly changing planet. Such stewardship views managers as an integral part of the systems they manage. It has been defined as a strategy to respond to and shape social-ecological systems under conditions of uncertainty and change to sustain the supply and opportunities for use of ecosystem services to support human well-being (Chapin et al. 2009, 2010). Hence, stewardship is an active shaping of pathways of social-ecological change. Ecosystem stewardship integrates reducing vulnerability to expected changes, fostering resilience to sustain desirable conditions in the face of perturbations and uncertainty, and transforming from undesirable trajectories when opportunities emerge (Chapin et al. 2010, 2015).

Obviously, stewardship is not just about the management of ecosystem services but about the social, economic, and cultural contexts in which this management operates and how issues like justice, power, and politics shape the operation of socialecological systems and the institutional and governance challenges that this entails (e.g., Leach et al. 2012, Mathevet et al. 2016). Respecting peoples' preferences, wishes, and values, and combatting injustice are fundamental ethical issues and challenges in the context of human well-being in the Anthropocene. But, if sustainability is of concern, focusing primarily on human well-being and social resilience while remaining disconnected from the biosphere and its stewardship is not a recipe for long-term sustainability. The intertwined nature of social-ecological systems and the need to reconnect development to the biosphere and the dynamics of the Earth system may become marginalized in the analysis and in the actions, if at all taken into account. What is somewhat surprising is that the ontologies of many approaches concerned with fundamental issues of human well-being and sustainability still seem to be rather blind to the significance of development in tune with the biosphere. It seems to us that many human-centered discourses have still to recognize the humans-in-nature reality of living in the Anthropocene (Westley et al. 2011, Hackman et al. 2013, Brondizio et al. 2016).

Stewardship of landscapes and seascapes requires continuous learning and knowledge generation across knowledge systems about social-ecological systems and ecosystem services and their dynamics (e.g., Raymond et al. 2010, Takeuchi 2010, Brondizio and Le Tourneau 2016). It requires skills and competences from applying and utilizing existing experiences embedded in, e.g., local and traditional knowledge systems and institutions, to the experimenting, innovating, and development of new approaches for stewardship like adaptive and transformative governance (e. g., Folke et al. 2005, Chaffin et al. 2016). Collaborative platforms (e.g., the Program on Ecosystem Change and Society, Carpenter et al 2012; the Natural Capital Project, Guerry et al. 2015; the Integrated History and future of People on Earth [IHOPE], Costanza et al. 2012) combining diverse types of knowledge for understanding complex social-ecological systems are emerging that try to learn from history and replicate and scale up these 
approaches. New initiatives are explicitly taking into account and respecting traditional and indigenous knowledge systems and cosmologies as part of stewardship efforts of landscapes and seascapes (Tengö et al. 2014). Many of those practice ecosystem management and build local site-specific ecological knowledge, thus serving as "cultural stewards of wildlife habitats" (Nabhan 1997) and are carriers of institutional and social memory of resource and ecosystem dynamics, with observations that often include understanding of long-term and large-scale changes (Berkes and Folke 1998, 2002).

In other words, biosphere stewardship is about finding pathways for biosphere-based sustainable developments with stewardship engaging people in management and governance that operates in synergy with the life-supporting environment and the ecosystem services generated. This requires social and ecological understanding at many scales and across scales and in diverse contexts, with collaboration of diverse actors and institutions in multilevel often polycentric governance systems, continuous learning with change, acting on power and conflict, innovating, and generating experience and adaptive capacity for dealing with moving targets like social-ecological systems and their intertwined dynamics in the Anthropocene (e.g., Armitage et al. 2009, Ekstrom and Young 2009, Galaz et al. 2011, Robards et al. 2011, Plieninger and Beiling 2012, Cosens 2013, Merrie and Olsson 2014, Fischer et al. 2015, Luthe and Wyss 2015, Biermann et al. 2016, Karpouzoglou et al. 2016).

The global research platform Future Earth is pushing for collaborations across the disciplines, knowledge systems, and regions of the world to develop the understanding, capacity, and approaches required to better harness science in order to address the sustainability challenges ahead. Such efforts have the potential to counteract erosion of biosphere capital that will put constraints on development efforts and poverty alleviation and may trigger migration. Policies and incentives creating identities for people to be skilful stewards of the land and the seas in a biosphere context are urgently needed. Pride, respect, and dignity could be restored by redirecting land use for bulk production to biosphere stewardship of a diverse landscape mosaic and the quality of multiple ecosystem services for the benefit of rural communities and urban residents.

Hence, improved biosphere stewardship in the Anthropocene is not a top-down global approach enforced on people, nor solely a bottom-up approach. It is a process engaging people to collaborate across levels and scales and with shared visions and creativity framed by proper institutions, continuously learning and gaining experience and building capacity to live with change, adapt, and transform. It is about managing and governing for emergence, what it means to be human in relation to the biosphere and the Earth system. It could be viewed as an emerging ethic that embodies the responsible relationship of humans as part of and dependent on the biosphere.

Numerous decisions, incentives, power structures, that operate as part of political, economic, institutional constraints and opportunities, continue to shape biosphere capacity, challenging the long-term sustainability of humanity in the Anthropocene (Steffen et al. 2015a, Biermann et al. 2016). Understanding diverse contexts of humans as "dwelling in the biosphere" (Cooke et al. 2016) and shaping it in different ways is of significance in biosphere stewardship (Folke et al. 2011, Williams et al. 2015). Investigations of issues like power dynamics, distribution of benefits, or poverty alleviation need to be connected to the vision of biosphere stewardship for human well-being (Fischer et al. 2015). It is about finding ways of development for human wellbeing in collaboration with the biosphere foundation. Fulfilling social goals in the short term may be necessary but it does not automatically lead to sustainability in the longer term.

The Anthropocene calls for rapid transformations toward global sustainability (Westley et al. 2011, O'Brien 2012). Seen in light of local and regional differences and contexts, and multiple ways of knowing and acting, it will allow for novel analysis of issue-based challenges in the context of a global understanding (Biermann et al. 2016). We stress that stewardship framed within biospherebased sustainable development is essential for humanity to be able to prosper on a resilient planet. New approaches and perspectives of such stewardship will continue to emerge with comparison and constructive collaboration of rich and diverse legacies, insights, findings, and perspectives of the natural science, social sciences, and the humanities.

\section{CONCLUSIONS - RECONNECTING DEVELOPMENT TO THE BIOSPHERE}

The social-ecological resilience approach as outlined here is an approach whereby humans and nature are studied as an integrated whole, not as separated parts. Humanity is embedded in the biosphere. Nature is inside us as much as we are inside nature. In this sense people, irrespective of social and cultural contexts, coevolve with the planet and our beliefs, perceptions, and choices shape our actions, technologies, and future in the biosphere in sustainable or unsustainable ways. Fundamental issues for humanity like democracy, health, poverty, inequality, power, justice, human rights, security, and peace all rest on the lifesupport capacity and resilience of the biosphere. The biosphere provides preconditions for achieving and sustaining dignity in human relations.

Hence, the social-ecological resilience approach emphasizes that humans and well-being fundamentally rest on the capacity of the biosphere to sustain us, irrespective of whether or not people recognize this dependence. It also makes clear that it is how we choose to view our relation to the biosphere in the globalized world and how we choose to act that will guide people in diverse contexts and humanity as a whole to sustainability or not. A key challenge for humanity in the present situation is to understand its new role as a dominant force in the operation of the biosphere and how it shapes the broader Earth system and to transform actions, technologies, and developments to fit the new reality of the Anthropocene. For the sake of humankind, it is time to start accounting for and investing in natural capital, in active stewardship of landscapes and seascapes, and in the new global context of the Anthropocene. It is time to mobilize ingenuity, innovation, technology, and collaboration and enhance options and flexibility for development to operate in concert with the biosphere. It is high time to reconnect approaches and perspectives on development to the biosphere foundation. It is a precondition for sustainability for people on Earth, hence, the need for a biosphere-based sustainability science. 
Responses to this article can be read online at:

http://www.ecologyandsociety.org/issues/responses. php/8748

\section{Acknowledgments:}

This work is supported by grants from the Beijer Foundation, the Erling-Persson Family Foundation, Marianne and Marcus Wallenberg Foundation, as well as from Mistra for core funding and Sida for the GRAID programme of the Stockholm Resilience Centre. The work contributes to the Program on Ecosystem Change and Society (www.pecs-science.org).

\section{LITERATURE CITED}

Acheson, J. M. 2003. Capturing the commons: devising institutions to manage the Maine lobster industry. University Press of New England, Lebanon, New Hampshire, USA.

Adger, W. N., H. Eakin, and A. Winkels. 2009. Nested and teleconnected vulnerabilities to environmental change. Frontiers in Ecology and the Environment 7:150-157. http://dx.doi. org/10.1890/070148

Andersson, E., S. Barthel, S. Borgström, J. Colding, T. Elmqvist, C. Folke, and Å. Gren. 2014. Reconnecting cities to the biosphere: stewardship of green infrastructure and urban ecosystem services. Ambio 43:445-453. http://dx.doi.org/10.1007/s13280-014-0506-y

Armitage, D. R., R. Plummer, F. Berkes, R. I. Arthur, A. T. Charles, I. J. Davidson-Hunt, A. P. Diduck, N. C. Doubleday, D. S. Johnson, M. Marschke, P. McConney, E. W. Pinkerton, and E. K. Wollenberg. 2009. Adaptive co-management for socialecological complexity. Frontiers in Ecology and the Environment 7:95-102. http://dx.doi.org/10.1890/070089

Bai, X., S. van der Leeuw, K. O’Brien, F. Berkhout, F. Biermann, E. S. Brondizio, C. Cudennec, J. Dearing, A. Duraiappah, M. Glaser, A. Revkin, W. Steffen, and J. Syvitski. 2016. Plausible and desirable futures in the Anthropocene: a new research agenda. Global Environmental Change 39:351-362. http://dx.doi. org/10.1016/j.gloenvcha.2015.09.017

Baland, J.-M., and J.-P. Platteau. 1996. Halting degradation of natural resources: Is there a role for rural communities. Food and Agricultural Organization of the United Nations, Rome, Italy.

Berkes, F., and C. Folke. 1992. A systems perspective on the interrelations between natural, human-made and cultural capital. Ecological Economics 5:1-8. http://dx.doi.org/10.1016/0921-8009 (92)90017-M

Berkes, F., and C. Folke, editors. 1998. Linking social and ecological systems: management practices and social mechanisms for building resilience. Cambridge University Press, Cambridge, UK

Berkes, F., and C. Folke. 2002. Back to the future: ecosystem dynamics and local knowledge. Pages 121-146 in L. H. Gunderson, and C. S. Holling, editors. Panarchy: understanding transformations in human and natural systems. Island, Washington, D.C., USA.
Berkes, F., T. P. Hughes, R. S. Steneck, J. A. Wilson, D. R. Bellwood, B. Crona, C. Folke, L. H. Gunderson, H. M. Leslie, J. Norberg, M. Nyström, P. Olsson, H. Österblom, M. Scheffer, and B. Worm. 2006. Globalization, roving bandits, and marine resources. Science 311:1557-1558. http://dx.doi.org/10.1126/ science. 1122804

Bettencourt, L. M. A., and J. Kaur. 2011. Evolution and structure of sustainability science. Proceedings of the National Academy of Sciences 108:19540-19545. http://dx.doi.org/10.1073/pnas.1102712108

Biermann, F., X. Bai, N. Bondre, W. Broadgate, C.-T. A. Chen, O. P. Dube, J. W. Erisman, M. Glaser, S. van der Hel, M. C. Lemos, S. Seitzinger, and K. C. Seto. 2016. Down to Earth: contextualizing the Anthropocene. Global Environmental Change 39:341-350. http://dx.doi.org/10.1016/j.gloenvcha.2015.11.004

Biggs, D., R. Biggs, V. Dakos, R. J. Scholes, and M. Schoon. 2011. Are we entering an era of concatenated global crises? Ecology and Society 16(2):27. [online] URL: http://www.ecologyandsociety. org/vol16/iss $2 / \operatorname{art} 27 /$

Biggs, R., M. Schlüter, D. Biggs, E. L. Bohensky, S. BurnSilver, G. Cundill, V. Dakos, T. M. Daw, L. S. Evans, K. Kotschy, A. M. Leitch, C. Meek, A. Quinlan, C. Raudsepp-Hearne, M. D. Robarbs, M. L. Schoon, L. Schultz, and P. C. West. 2012. Toward principles for enhancing the resilience of ecosystem services. Annual Review of Environment and Resources 37:421-448. http:// dx.doi.org/10.1146/annurev-environ-051211-123836

Biggs, R., M. Schlüter, and M. L. Schoon, editors. 2015. Principles for building resilience: sustaining ecosystem services in socialecological systems. Cambridge University Press, Cambridge, UK. http://dx.doi.org/10.1017/cbo9781316014240

Bodin, Ö., M. Tengö, A. Norman, J. Lundberg, and T. Elmqvist. 2006. The value of small size: loss of forest patches and ecological thresholds in southern Madagascar. Ecological Applications 16:440-451. http://dx.doi.org/10.1890/1051-0761(2006)016[0440: TVOSSL]2.0.CO:2

Boulding, K. E. 1966. The economics of the coming spaceship Earth. Pages 3-14 in H. Jarrett, editor. Environmental quality in a growing economy. Resources for the Future/Johns Hopkins University Press, Baltimore, Maryland, USA.

Brashares, J. S., P. Arcese, M. K. Sam, P. B. Coppolillo, A. R. E. Sinclair, and A. Balmford. 2004. Bushmeat hunting, wildlife declines, and fish supply in West Africa. Science 306:1180-1183. http://dx.doi.org/10.1126/science.1102425

Brondizio, E. S., and F.-M. Le Tourneau. 2016. Environmental governance for all. Science 352:1272-1273. http://dx.doi. org/10.1126/science.aaf5122

Brondizio, E. S., K. O’Brien, X. Bai, F. Biermann, W. Steffen, F. Berkhout, C. Cudennec, M. C. Lemos, A. Wolfe, J. PalmaOliveira, and C.-T. A. Chen. 2016. Re-conceptualizing the Anthropocene: a call for collaboration. Global Environmental Change 39:318-327. http://dx.doi.org/10.1016/j.gloenvcha.2016.02.006

Carpenter, S. R., W. A. Brock, C. Folke, E. H. van Nes, and M. Scheffer. 2015. Allowing variance may enlarge the safe operating space for exploited ecosystems. Proceedings of the National Academy of Sciences 112:14384-14389. http://dx.doi.org/10.1073/ pnas. 1511804112 
Carpenter, S. R., C. Folke, A. Norström, O. Olsson, L. Schultz, B. Agarwal, P. Balvanera, B. Campbell, J. C. Castilla, W. Cramer, R. DeFries, P. Eyzaguirre, T. P. Hughes, S. Polasky, Z. Sanusi, R. Scholes, and M. Spierenburg. 2012. Program on ecosystem change and society: an international research strategy for integrated social-ecological systems. Current Opinion in Environmental Sustainability 4:134-138. http://dx.doi.org/10.1016/j.cosust.2012.01.001

Carpenter, S. R., H. A. Mooney, J. Agard, D. Capistrano, R. S. DeFries, S. Diaz, T. Dietz, A. K. Duraiappah, A. Oteng-Yeboah, H. M. Pereira, C. Perrings, W. V. Reid, J. Sarukhan, R. J. Scholes, and A. Whyte. 2009. Science for managing ecosystem services: beyond the Millennium Ecosystem Assessment. Proceedings of the National Academy of Sciences 106:1305-1312. http://dx.doi. org/10.1073/pnas.0808772106

Chaffin, B. C., A. S. Garmestani, L. H. Gunderson, M. Harm Benson, D. G. Angeler, C. A. Arnold, B. Cosens, R. Kundis Craig, J. B. Ruhl, and C. R. Allen. 2016. Transformative environmental governance. Annual Review of Environment and Resources 41. http://dx.doi.org/10.1146/annurev-environ-110615-085817

Chapin III, F. S., S. R. Carpenter, G. P. Kofinas, C. Folke, N. Abel, W. C. Clark, P. Olsson, D. M. Stafford Smith, B. H. Walker, O. R. Young, F. Berkes, R. Biggs, J. M. Grove, R. L. Naylor, E. Pinkerton, W. Steffen, and F. J. Swanson. 2010. Ecosystem stewardship: sustainability strategies for a rapidly changing planet. Trends in Ecology and Evolution 25:241-249. http://dx.doi. org/10.1016/j.tree.2009.10.008

Chapin III, F. S., G. P. Kofinas, and C. Folke, editors. 2009. Principles of ecosystem stewardship: resilience-based natural resource management in a changing world. Springer Verlag, New York, New York, USA.

Chapin III, F. S., M. Sommerkorn, M. D. Robards, and K. Hillmer-Pegram. 2015. Ecosystem stewardship: a resilience framework for arctic conservation. Global Environmental Change 34:207-217. http://dx.doi.org/10.1016/j.gloenvcha.2015.07.003

Cifdaloz, O., A. Regmi, J. M. Anderies, and A. A. Rodriguez. 2010. Robustness, vulnerability, and adaptive capacity in smallscale social-ecological systems: the Pumpa Irrigation system in Nepal. Ecology and Society 15(3):39. [online] URL: http://www. ecologyandsociety.org/vol15/iss3/art39/

Clark, W. C. 2007. Sustainability science: a room of its own. Proceedings of the National Academy of Sciences 104:1737-1738. http://dx.doi.org/10.1073/pnas.0611291104

Clark, W. C., and R. E. Munn, editors. 1986. Sustainable development of the biosphere. Cambridge University Press, Cambridge, UK.

Cooke, B., S. West, and W. J. Boonstra. 2016. Dwelling in the biosphere: exploring an embodied human-environment connection in resilience thinking. Sustainability Science 11:831-843. http://dx.doi.org/10.1007/s11625-016-0367-3

Cosens, B. A. 2013. Legitimacy, adaptation, and resilience in ecosystem management. Ecology and Society 18(1):3. http://dx. doi.org/10.5751/ES-05093-180103

Costanza, R., editor. 1991. Ecological economics: the science and management of sustainability. Columbia University Press, New York, New York, USA.
Costanza, R., C. Cleveland, and C. Perrings, editors. 1997. The development of ecological economics. Edward Elgar, Cheltenham, $\mathrm{UK}$.

Costanza, R., and H. E. Daly. 1992. Natural capital and sustainable development. Conservation Biology 6:37-46. http://dx. doi.org/10.1046/j.1523-1739.1992.610037.x

Costanza, R., S. C. Farber, and J. Maxwell. 1989. Valuation and management of wetland ecosystems. Ecological Economics 1:335-361. http://dx.doi.org/10.1016/0921-8009(89)90014-1

Costanza, R., S. van der Leeuw, K. Hibbard, S. Aulenbach, S. Brewer, M. Burek, S. Cornell, C. Crumley, J. Dearing, C. Folke, L. Graumlich, M. Hegmon, S. Heckbert, S. T. Jackson, I. Kubiszewski, V. Scarborough, P. Sinclair, S. Sörlin, and W. Steffen. 2012. Developing an Integrated History and future of People on Earth (IHOPE). Current Opinion in Environmental Sustainability 4:106-114. http://dx.doi.org/10.1016/i.cosust.2012.01.010

Crona, B. I., T. M. Daw, W. Swartz, A. V. Norström, M. Nyström, M. Thyresson, C. Folke, J. Hentati-Sundberg H. Österblom, L. Deutsch, and M. Troell. 2015a. Masked, diluted, drowned out: global seafood trade weakens signals from marine ecosystems. Fish and Fisheries. http://dx.doi.org/10.1111/faf.12109

Crona, B. I., T. Van Holt, M. Petersson, T. M. Daw, and E. Buchary. 2015b. Using social-ecological syndromes to understand impacts of international seafood trade on small-scale fisheries. Global Environmental Change 35:162-175. http://dx.doi. org/10.1016/j.gloenvcha.2015.07.006

Cumming, G. S., A. Buerkert, E. M. Hoffmann, E. Schlecht, S. von Cramon-Taubadel, and T. Tscharntke. 2014. Implications of agricultural transitions and urbanization for ecosystem services. Nature 515:50-57. http://dx.doi.org/10.1038/nature13945

Daily, G. C., editor. 1997. Nature's services: societal dependence on natural ecosystems. Island, Washington, D.C., USA.

Daly, H. E. 1991. Steady-state economics. Island, Washington, D. C., USA. http://dx.doi.org/10.4337/9781783479979.00007

Daly, H. E. and J. B. Cobb. 1989. For the common good: redirecting the economy towards community, the environment and sustainable development. Beacon, Boston, Massachusetts, USA.

Dasgupta, P. 1995. An inquiry into well-being and destitution. Oxford University Press, Oxford, UK. http://dx.doi. org/10.1093/0198288352.001.0001

Dasgupta, P., and I. Serageldin, editors. 1999. Social capital: a multifaceted perspective. The World Bank, Washington, D.C., USA. http://dx.doi.org/10.1596/0-8213-4562-1

Davis, J. H., F. D. Schoorman, and L. Donaldson. 1997. Toward a stewardship theory of management. Academy of Management Review 22:20-47.

de Groot, R. S. 1992. Functions of nature: evaluation of nature in environmental planning, management and decision making. Wolters-Noordhoff BV, Groningen, The Netherlands.

Donaldson, L., and J. H. Davis. 1991. Stewardship theory or agency theory: CEO governance and shareholder returns. Australian Journal of Management 16:49-64. http://dx.doi. org/10.1177/031289629101600103 
Ehrlich P. R., and A. E. Ehrlich. 2008. The dominant animal: human evolution and the environment. Island, Washington, D.C., USA.

Ehrlich, P. R., and H. A. Mooney. 1983. Extinction, substitutions, and ecosystem services. BioScience 33:248-254. http://dx.doi. org/10.2307/1309037

Ekins, P., S. Simon, L. Deutsch, C. Folke, and R. de Groot. 2003. A framework for the practical application of the concepts of critical natural capital and strong sustainability. Ecological Economics 44:165-185. http://dx.doi.org/10.1016/S0921-8009(02) $\underline{00272-0}$

Ekstrom, J. A., and O. R. Young. 2009. Evaluating functional fit between a set of institutions and an ecosystem. Ecology and Society 14(2):16. [online] URL: http://www.ecologyandsociety. org/vol14/iss2/art16/

Ellis, E. C. 2015. Ecology in an anthropogenic biosphere. Ecological Monographs 85:287-331. http://dx.doi.org/10.1890/14-2274.1

Eriksson, H., H. Österblom, B. Crona, M. Troell, N. Andrew, J. Wilen, and C. Folke. 2015. Contagious exploitation of marine resources. Frontiers in Ecology and the Environment 13:435-440. http://dx.doi.org/10.1890/140312

Fairhead, J., M. Leach, and I. Scoones. 2012. Green grabbing: a new appropriation of nature? Journal of Peasant Studies 39:237-261. http://dx.doi.org/10.1080/03066150.2012.671770

Fischer, J., T. A. Gardner, E. M. Bennett, P. Balvanera, R. Biggs, S. Carpenter, T. Daw, C. Folke, R. Hill, T. P. Hughes, T. Luthe, M. Maass, M. Meacham, A. V. Norström, G. Peterson, C. Queiroz, R. Seppelt, M. Spierenburg, J. Tenhunen. 2015. Advancing sustainability through mainstreaming a socialecological systems perspective. Current Opinion in Environmental Sustainability 14:144-149. http://dx.doi.org/10.1016/j.cosust.2015.06.002

Folke, C. 1991. Socio-economic dependence on the lifesupporting environment. Pages 77-94 in C. Folke and T. Kåberger, editors. Linking the natural environment and the economy: essays from the Eco-Eco Group. Kluwer Academic, Dordrecht, The Netherlands. http://dx.doi.org/10.1007/978-94-017-6406-3 5

Folke, C. 2006. Resilience: the emergence of a perspective for social-ecological systems analyses. Global Environmental Change 16:253-267. http://dx.doi.org/10.1016/j.gloenvcha.2006.04.002

Folke, C. 2016. Resilience. In H. H. Shugart, editor. Oxford research encyclopedia of environmental science. Oxford University Press, New York, New York, USA, in press. [online] URL: http:// environmentalscience.oxfordre.com/

Folke, C., S. R. Carpenter, B. Walker, M. Scheffer, T. Chapin, and J. Rockström. 2010. Resilience thinking: integrating resilience adaptability and transformability. Ecology and Society 15(4):20. [online] URL: http://www.ecologyandsociety.org/vol15/iss4/ $\underline{\operatorname{art} 20 /}$

Folke, C., S. R. Carpenter, B. Walker, M. Scheffer, T. Elmqvist, L. Gunderson, and C. S. Holling. 2004. Regime shifts, resilience, and biodiversity in ecosystem management. Annual Review of Ecology, Evolution and Systematics 35:557-581. http://dx.doi. org/10.1146/annurev.ecolsys.35.021103.105711
Folke, C., J. Colding, and F. Berkes. 2003. Synthesis: building resilience and adaptive capacity in social-ecological systems. Pages 352-387 in F. Berkes, J. Colding and C. Folke, editors. Navigating social-ecological systems: building resilience for complexity and change. Cambridge University Press, Cambridge, UK. http://dx.doi.org/10.1017/cbo9780511541957.020

Folke, C., T. Hahn, P. Olsson, and J. Norberg. 2005. Adaptive governance of social-ecological systems. Annual Review of Environment and Resources 30:441-473. http://dx.doi.org/10.1146/ annurev.energy.30.050504.144511

Folke, C., M. Hammer, and A. M. Jansson. 1991. The life-support value of ecosystems: a case study of the Baltic Sea Region. Ecological Economics 3:123-137. http://dx.doi.org/10.1016/0921-8009 (91)90013-5

Folke, C., Å. Jansson, J. Larsson, and R. Costanza. 1997. Ecosystem appropriation by cities. Ambio 26:167-172.

Folke, C., Å. Jansson, J. Rockström, P. Olsson, S. R. Carpenter, F. S. Chapin III, A.-S. Crépin, G. Daily, K. Danell, J. Ebbesson, T. Elmqvist, V. Galaz, F. Moberg, M. Nilsson, H. Österblom, E. Ostrom, A. Persson, G. Peterson, S. Polasky, W. Steffen, B. Walker, and F. Westley. 2011. Reconnecting to the biosphere. Ambio 40:719-738. http://dx.doi.org/10.1007/s13280-011-0184-y

Gadgil, M., F. Berkes, and C. Folke. 1993. Indigenous knowledge for biodiversity conservation. Ambio 22:151-156.

Galaz, V. 2014. Global environmental governance, technology and politics: the Anthropocene gap. Edward Elgar, Cheltenham, UK. http://dx.doi.org/10.4337/9781781955550

Galaz, V., B. Crona, H. Österblom, P. Olsson, and C. Folke. 2012. Polycentric systems and interacting planetary boundaries: emerging governance of climate change - ocean acidification marine biodiversity. Ecological Economics 81:21-32. http://dx. doi.org/10.1016/j.ecolecon.2011.11.012

Galaz, V., F. Moberg, E.-K. Olsson, E. Paglia, and C. Parker. 2011. Institutional and political leadership dimensions of cascading ecological crises. Public Administration 89:361-380. http://dx.doi.org/10.1111/j.1467-9299.2010.01883.x

Golden, C. D., E. H. Allison, W. W. L. Cheung, M. M. Dey, B. S. Halpern, D. J. McCauley, M. Smith, B. Vaitla, D. Zeller, and S. S. Myers. 2016. Nutrition: fall in fish catch threatens human health. Nature 534:317-320. http://dx.doi.org/10.1038/534317a

Griggs, D., M. Stafford-Smith, O. Gaffney, J. Rockström, M. C. Öhman, P. Shyamsundar, W. Steffen, G. Glaser, N. Kanie, and I. Noble. 2013. Policy: sustainable development goals for people and planet. Nature 495:305-307. http://dx.doi.org/10.1038/495305a

Grimm, N. B., S. H. Faeth, N. E. Golubiewski, C. L. Redman, J. Wu, X. Bai, and J. M. Briggs. 2008. Global change and the ecology of cities. Science 319:756-760. http://dx.doi.org/10.1126/ science. 1150195

Guerry, A. D., S. Polasky, J. Lubchenco, R. Chaplin-Kramer, G. C. Daily, R. Griffin, M. Ruckelshaus, I. J. Bateman, A. Duraiappah, T. Elmqvist, M. W. Feldman, C. Folke, J. Hoekstra, P. M. Kareiva, B. L. Keeler, S. Li, E. McKenzie, Z. Ouyang, B. Reyers, T. H. Ricketts, J. Rockström, H. Tallis, and B. Vira. 2015. Natural capital and ecosystem services informing decisions: from 
promise to practice. Proceedings of the National Academy of Sciences 112:7348-7355. http://dx.doi.org/10.1073/pnas.1503751112

Gunderson, L. H., and C. S. Holling, editors. 2002. Panarchy: understanding transformations in human and natural systems. Island, Washington, D.C., USA.

Hackman, H., F. Caillods, S. Moser, F. Berkhout, L. Daniel, D. Feliciano, O. Martin and E. Marques. 2013. World social science report: 2013. Changing global environments. UNESCO, ISSC, and OECD, Paris, France.

Haskins, M. E., J. Liedtka, and J. Rosenblum. 1998. Beyond teams: toward an ethic of collaboration. Organizational Dynamics 26:34-50. http://dx.doi.org/10.1016/S0090-2616(98)90004-3

Helbing, D. 2013. Globally networked risks and how to respond. Nature 497:51-59. http://dx.doi.org/10.1038/nature12047

Hernandez, M. 2012. Toward an understanding of the psychology of stewardship. Academy of Management Review 37:172-193. http://dx.doi.org/10.5465/amr.2010.0363

Holling, C. S. 1973. Resilience and stability of ecological systems. Annual Review of Ecology and Systematics 4:1-23. http://dx.doi. org/10.1146/annurev.es.04.110173.000245

Holling, C. S. 1995. An ecologist's view of the Malthusian conflict. Pages 79-103 in K. Lindahl Kiessling and H. Landberg, editors. Population, economic development and the environment. Oxford University Press, Oxford, UK.

Holling, C. S., F. Berkes, and C. Folke. 1998. Science, sustainability, and resource management. Pages 342-362 in F. Berkes and C. Folke, editors. Linking social and ecological systems: management practices and social mechanisms for building resilience. Cambridge University Press, Cambridge, UK.

Holling, C. S., and G. K. Meffe. 1996. Command and control and the pathology of natural resource management. Conservation Biology 10:328-337. http://dx.doi.org/10.1046/j.1523-1739.1996.10020328. $\underline{\mathrm{x}}$

Homer-Dixon, T., B. Walker, R. Biggs, A.-S. Crepin, C. Folke, E. F. Lambin, G. D. Peterson, J. Rockström, M. Scheffer, W. Steffen, and M. Troell. 2015. Synchronous failure: the emerging causal architecture of global crisis. Ecology and Society 20(3):6. http:// dx.doi.org/10.5751/es-07681-200306

Hughes, T. P., C. Linares, V. Dakos, I. A. van de Leemput, and E. H. van Nes. 2013. Living dangerously on borrowed time during slow, unrecognized regime shifts. Trends in Ecology and Evolution 28:149-155. http://dx.doi.org/10.1016/j.tree.2012.08.022

Jansson, A. M., M. Hammer, C. Folke, and R. Costanza, editors. 1994. Investing in natural capital: the ecological economics approach to sustainability. Island, Washington, D.C., USA.

Kallis, G., and R. B. Norgaard 2010. Coevolutionary ecological economics. Ecological Economics 69:690-699. http://dx.doi. org/10.1016/j.ecolecon.2009.09.017

Kareiva, P., H. Tallis, T. H. Ricketts, G. C. Daily, and S. Polasky, editors. 2011. Natural capital: theory and practice of mapping ecosystem services. Oxford University Press, Oxford, UK. http:// dx.doi.org/10.1093/acprof:0so/9780199588992.001.0001
Karpouzoglou, T., A. Dewulf, and J. Clark. 2016. Advancing adaptive governance of social-ecological systems through theoretical multiplicity. Environmental Science \& Policy 57:1-9. http://dx.doi.org/10.1016/j.envsci.2015.11.011

Kates, R. W., W. C. Clark, R. Corell, J. M. Hall, C. C. Jaeger, I. Lowe, J. J. McCarthy, H. J. Schellnhuber, B. Bolin, N. M. Dickson, S. Faucheux, G. C. Gallopin, A. Grübler, B. Huntley, J. Jäger, N. S. Jodha, R. E. Kasperson, A. Mabogunje, P. Matson, H. Mooney, B. Moore III, T. O'Riordan, and U. Svedin. 2001. Sustainability science. Science 292:641-642. http://dx.doi.org/10.1126/science.1059386

Komiyama, H., and K. Takeuchi. 2006. Sustainability science: building a new discipline. Sustainability Science 1:1-6. http://dx. doi.org/10.1007/s11625-006-0007-4

Lambin, E. F., and P. Meyfroidt. 2011. Global land use change, economic globalization, and the looming land scarcity. Proceedings of the National Academy of Sciences 108:3465-3472. http://dx.doi.org/10.1073/pnas. 1100480108

Lansing, J. S. 2003. Complex adaptive systems. Annual Review of Anthropology. 32:183-204. http://dx.doi.org/10.1146/annurev. anthro.32.061002.093440

Lazarus, E. D. 2014. Land grabbing as a driver of environmental change. Area 46:74-82. http://dx.doi.org/10.1111/area.12072

Leach, M., J. Rockström, P. Raskin, I. Scoones, A. C. Stirling, A. Smith, J. Thompson, E. Millstone, A. Ely, E. Arond, C. Folke, and P. Olsson. 2012. Transforming innovation for sustainability. Ecology and Society 17(2):11. http://dx.doi.org/10.5751/ es-04933-170211

Lenton, T. M. 2016. Earth system science: a very short introduction. Oxford University Press, Oxford, UK. http://dx.doi.org/10.1093/ actrade/9780198718871.001.0001

Lenton, T. M., H. Held, E. Kriegler, J. W. Hall, W. Lucht, S. Rahmstorf, and H. J. Schellnhuber. 2008. Tipping elements in the Earth's climate system. Proceedings of the National Academy of Sciences 105:1786-1793. http://dx.doi.org/10.1073/pnas.0705414105

Levin, S. A. 1999. Fragile dominion: complexity and the commons. Helix Books, Perseus, Cambridge, Massachusetts, USA.

Levin, S. A, T. Xepapadeas, A.-S. Crepin, J. Norberg, A. de Zeeuw, C. Folke, T. Hughes, K. Arrow, S. Barrett, G. Daily, P. Ehrlich, N. Kautsky, K.-G. Mäler, S. Polasky, M. Troell, J. R. Vincent, and B. Walker. 2013. Social-ecological systems as complex adaptive systems: modeling and policy implications? Environment and Development Economics 18:111-132. http://dx.doi.org/10.1017/ S1355770X12000460

Liu, J., T. Dietz, S. R. Carpenter, M. Alberti, C. Folke, E. Moran, A. N. Pell, P. Deadman, T. Kratz, J. Lubchenco, E. Ostrom, Z. Ouyang, W. Provencher, C. L. Redman, S. H. Schneider, and W. W. Taylor. 2007. Complexity of coupled human and natural systems. Science 317:1513-1516. $\underline{\text { http://dx.doi.org/10.1126/ }}$ science. 1144004

Liu, J., V. Hull, M. Batistella, R. DeFries, T. Dietz, F. Fu, T. W. Hertel, R. C. Izaurralde, E. F. Lambin, S. Li, L. A. Martinelli, W. J. McConnell, E. F. Moran, R. Naylor, Z. Ouyang, K. R. Polenske, A. Reenberg, G. de Miranda Rocha, C. S. Simmons, P. H. Verburg, P. M. Vitousek, F. Zhang, and C. Zhu. 2013. Framing 
sustainability in a telecoupled world. Ecology and Society 18 (2):26. http://dx.doi.org/10.5751/es-05873-180226

Luthe, T., and R. Wyss. 2015. Introducing adaptive waves as a concept to inform mental models of resilience. Sustainability Science 10:673-685. http://dx.doi.org/10.1007/s11625-015-0316-6

Mace, G. M., B. Reyers, R. Alkemade, R. Biggs, F. S. Chapin III, S. E. Cornell, S. Díaz, S. Jennings, P. Leadley, P. J. Mumby, A. Purvis, R. J. Scholes, A. W. R. Seddon, M. Solan, W. Steffen, and G. Woodward. 2014. Approaches to defining a planetary boundary for biodiversity. Global Environmental Change 28:289-297. http://dx.doi.org/10.1016/j.gloenvcha.2014.07.009

Mathevet, R., J. D. Thompson, C. Folke, and S. Chapin III. 2016. Protected areas and their surrounding territory: socioecological systems in the context of ecological solidarity. Ecological Applications 26:5-16. http://dx.doi.org/10.1890/14-0421

Matson, P., W. C. Clark, and K. Andersson. 2016. Pursuing sustainability: a guide to the science and practice. Princeton University Press, Princeton, New Jersey, USA.

McNeill, J. R. 2000. Something new under the sun: an environmental history of the twentieth century. W. W. Norton, New York, New York, USA.

Merrie, A., and P. Olsson. 2014. An innovation and agency perspective on the emergence and spread of Marine Spatial Planning. Marine Policy 44:366-374. http://dx.doi.org/10.1016/j. marpol.2013.10.006

Menyah, K. 2013. Stewardship theory. Pages 2322-2329 in S. O. Idowu, N. Capaldi, L. Zu, and A. Das Gupta, editors. Encyclopedia of corporate social responsibility. Springer Verlag, Berlin, Germany. http://dx.doi.org/10.1007/978-3-642-28036-8 107

Mora, C. 2014. Revisiting the environmental and socioeconomic effects of population growth: a fundamental but fading issue in modern scientific, public, and political circles. Ecology and Society 19(1):38. http://dx.doi.org/10.5751/es-06320-190138

Nabhan, G. P. 1997. Cultures of habitat: on nature, culture, and story. Counterpoint, Washington, D.C., USA.

Norgaard, R. B. 1989. The case for methodological pluralism. Ecological Economics 1:37-57. http://dx.doi.org/10.1016/0921-8009 (89)90023-2

Norgaard, R. B. 1994. Development betrayed: the end of progress and a coevolutionary revisioning of the future. Routledge, San Francisco, California, USA.

Nyström, M., A. V. Norström, T. Bleckner, M. de la Torre Castro, J. S. Eklöf, C. Folke, H. Österblom, R. S. Steneck, M. Thyresson, and M. Troell. 2012. Confronting feedbacks of degraded marine ecosystems. Ecosystems 15:695-710. http://dx.doi.org/10.1007/ s10021-012-9530-6

O'Brien, K. 2012. Global environmental change II: from adaptation to deliberate transformation. Progress in Human Geography 36:667-676. http://dx.doi.org/10.1177/0309132511425767

Odum, E. P. 1989. Ecology and our endangered life-support systems. Sinauer, Sunderland, Massachusetts, USA.

Odum, H. T. 1971. Environment, power, and society. WileyInterscience, New York, New York, USA.
Österblom, H., J.-B. Jouffray, C. Folke, B. Crona, M. Troell, A. Merrie, and J. Rockström. 2015. Transnational corporations as 'keystone actors' in marine ecosystem. PloS ONE 10(5):e0127533. http://dx.doi.org/10.1371/journal.pone.0127533

Palsson, G., B. Szerszynski, S. Sörlin, J. Marks, B. Avril, C. Crumley, H. Hackmann, P. Holm, J. Ingram, A. Kirman, M. Pardo Buendía, and R. Weehuizen. 2013. Reconceptualizing the 'Anthropos' in the Anthropocene: integrating the social sciences and humanities in global environmental change research. Environmental Science and Policy 28:3-13. http://dx.doi. org/10.1016/j.envsci.2012.11.004

Palumbi, S. R. 2001. The evolution explosion: how humans cause rapid evolutionary change. W. W. Norton, New York, New York, USA.

Perrings, C. A., C. Folke, and K.-G. Mäler. 1992. The ecology and economics of biodiversity loss: the research agenda. Ambio 21:201-211.

Piketty, T. 2014. Capital in the twenty-first century. Belknap Press of Harvard University Press, Cambridge, Massachusetts, USA. http://dx.doi.org/10.4159/9780674369542

Plieninger, T., and C. Bieling, editors. 2012. Resilience and the cultural landscape: understanding and managing change in humanshaped environments. Cambridge University Press, Cambridge, UK. http://dx.doi.org/10.1017/cbo9781139107778

Pretty, J., and H. Ward 2001. Social capital and the environment. World Development 29:209-227. http://dx.doi.org/10.1016/ S0305-750X(00)00098-X

Putnam, R. D. 2002. Democracies in flux: the evolution of social capital in contemporary society. Oxford University Press, Oxford, UK. http://dx.doi.org/10.1093/0195150899.001.0001

Raworth, K. 2012. A safe and just space for humanity. Oxfam Discussion Paper. Oxfam International, Oxford, UK.

Raymond, C. M., I. Fazey, M. S. Reed, L. C. Stringer, G. M. Robinson, and A. C. Evely. 2010. Integrating local and scientific knowledge for environmental management. Journal of Environmental Management 91:1766-1777. http://dx.doi.org/10.1016/ j.jenvman.2010.03.023

Redman, C. L. 1999. Human impact on ancient environments. University of Arizona Press, Tucson, Arizona, USA.

Robards, M. D., M. L. Schoon, C. L. Meek, and N. L. Engle. 2011. The importance of social drivers in the resilient provision of ecosystem services. Global Environmental Change 21:522-529. http://dx.doi.org/10.1016/j.gloenvcha.2010.12.004

Rocha, J. C., G. D. Peterson, and R. O. Biggs. 2015. Regime shifts in the Anthropocene: drivers, risks, and resilience. PLOS ONE 10 (8):e0134639. http://dx.doi.org/10.1371/journal.pone.0134639

Rockström, J., and M. Klum. 2015. Big world, small planet: abundance within planetary boundaries. Max Ström, Stockholm, Sweden.

Rockström, J., W. Steffen, K. Noone, Å. Persson, F. S. Chapin III, E. F. Lambin, T. M. Lenton, M. Scheffer, C. Folke, H. J. Schellnhuber, B. Nykvist, C. A. de Wit, T. Hughes, S. van der Leeuw, H. Rodhe, S. Sörlin, P. K. Snyder, R. Costanza, U. Svedin, 
M. Falkenmark, L. Karlberg, R. W. Corell, V. J. Fabry, J. Hansen, B. H. Walker, D. Liverman, K. Richardson, P. Crutzen, and J. A. Foley. 2009. A safe operating space for humanity. Nature 461:472-475. http://dx.doi.org/10.1038/461472a

Rockström, J., and P. Sukhdev. 2014. From MDGs to SDGs: transition to a development paradigm of human prosperity within a safe operating space on Earth. Input to the 11th session of the UN Open Working Group on Sustainable Development Goals, 30 April, 2014. UN, New York, New York, USA. [online] URL: http://www.icsu.org/science-for-policy/sustainable-developmentgoals-1/pdfs/Rockstrom Sukhdev input OWG UNEP FINAL. pdf

Rosling, H. 2010. Gapminder: a fact-based worldview. Gapminder, Stockholm, Sweden. [online] URL: http://www.gapminder.org/

Safarzyńska, K., and J. C. J. M. van den Bergh. 2010. Demandsupply coevolution with multiple increasing returns: policy analysis for unlocking and system transitions. Technological Forecasting and Social Change 77:297-317. http://dx.doi. org/10.1016/j.techfore.2009.07.001

Scheffer, M. 2009. Critical transitions in nature and society. Princeton University Press, Princeton, New Jersey, USA.

Scheffer, M., S. Carpenter, J. A. Foley, C. Folke, and B. Walker. 2001. Catastrophic shifts in ecosystems. Nature 413:591-596. http://dx.doi.org/10.1038/35098000

Schwartz, P. 1991. The art of the long view: planning for the future in an uncertain world. John Wiley \& Sons, New York, New York, USA.

Seto, K. C., A. Reenberg, C. G. Boone, M. Fragkias, D. Haase, T. Langanke, P. Marcotullio, D. K. Munroe, B. Olah, and D. Simon. 2012. Urban land teleconnections and sustainability. Proceedings of the National Academy of Sciences 109:7687-7692. http://dx.doi.org/10.1073/pnas.1117622109

Steffen, W., W. Broadgate, L. Deutsch, O. Gaffney, and C. Ludwig. 2015b. The trajectory of the Anthropocene: the great acceleration. Anthropocene Review. 2:81-98. http://dx.doi.org/10.1177/205301$\underline{9614564785}$

Steffen, W., P. J. Crutzen, and J. R. McNeill. 2007. The Anthropocene: Are humans now overwhelming the great forces of nature? Ambio 36:614-621. http://dx.doi.org/10.1579/0044-7447 (2007)36[614:taahno]2.0.co;2

Steffen, W., Å. Persson, L. Deutsch, J. Zalasiewicz, M. Williams, K. Richardson, C. Crumley, P. Crutzen, C. Folke, L. Gordon, M. Molina, V. Ramanathan, J. Rockström, M. Scheffer, H. J. Schellnhuber, and U. Svedin. 2011. The Anthropocene: from global change to planetary stewardship. Ambio 40:739-761. http:// dx.doi.org/10.1007/s13280-011-0185-X

Steffen, W., K. Richardson, J. Rockström, S. E. Cornell, I. Fetzer, E. M. Bennett, R. Biggs, S. R. Carpenter, W. de Vries, C. A. de Wit, C. Folke, D. Gerten, J. Heinke, G. M. Mace, L. M. Persson, V. Ramanathan, B. Reyers, and S. Sörlin. 2015a. Planetary boundaries: guiding human development on a changing planet. Science 347:6223 http://dx.doi.org/10.1126/science.1259855

Steffen, W., R. A. Sanderson, P. D. Tyson, J. Jäger, P. A. Matson, B. Moore III, F. Oldfield, K. Richardson, H. J. Schellnhuber, B.
L. Turner, R. J. Wasson. 2004. Global change and the earth system: a planet under pressure. Springer, New York, New York, USA.

Steneck, R. S., T. P. Hughes, J. E. Cinner, W. N. Adger, S. N. Arnold, F. Berkes, S. A. Boudreau, K. Brown, C. Folke, L. Gunderson, P. Olsson, M. Scheffer, E. Stephenson, B. Walker, J. Wilson, and B. Worm. 2011. Creation of a gilded trap by the high economic value of the Maine lobster fishery. Conservation Biology 25:904-912. http://dx.doi.org/10.1111/j.1523-1739.2011.01717.x

Sterner, T., M. Troell, J. Vincent, S. Aniyar, S. Barrett, W. Brock, S. Carpenter, K. Chopra, P. Ehrlich, M. Hoel, S. Levin, K.-G. Mäler, J. Norberg, L. Pihl, T. Söderqvist, J. Wilen, and A. Xepapadeas. 2006. Quick fixes for the environment: part of the solution or part of the problem? Environment 48(10):20-27. http:// dx.doi.org/10.3200/envt.48.10.20-27

Stiglitz, J. E. 2012. The price of inequality: how today's divided society endangers our future. W. W. Norton, New York, New York, USA.

Takeuchi, K. 2010. Rebuilding the relationship between people and nature: the Satoyama Initiative. Ecological Research 25:891-897. http://dx.doi.org/10.1007/s11284-010-0745-8

Takeuchi, K., T. Elmqvist, M. Hatakeyama, J. Kauffman, N. Turner, and D. Zhou. 2014. Using sustainability science to analyse social-ecological restoration in NE Japan after the great earthquake and tsunami of 2011. Sustainability Science 9:513-526. http://dx.doi.org/10.1007/s11625-014-0257-5

Tengö, M., E. S. Brondizio, T. Elmqvist, P. Malmer, and M. Spierenburg. 2014. Connecting diverse knowledge systems for enhanced ecosystem governance: the multiple evidence base approach. Ambio 43:579-591. http://dx.doi.org/10.1007/ s13280-014-0501-3

Tengö, M., K. Johansson, F. Rakotondrasoa, J. Lundberg, J. A. Andriamaherilala, J. A. Rakotoarisoa, and T. Elmqvist. 2007. Taboos and forest governance: informal protection of hot spot dry forest in Southern Madagascar. Ambio 36(8):683-691. http:// dx.doi.org/10.1579/0044-7447(2007)36[683:tafgip]2.0.c0;2

Tengö, M., and J. von Heland. 2012. Adaptive capacity of local indigenous institutions : the case of the taboo forests of southern Madagascar. Pages 37-74 in E. Boyd and C. Folke, editors. Adapting institutions: governance, complexity and socialecological resilience. Cambridge University Press, Cambridge, UK. http://dx.doi.org/10.1017/cbo9781139017237.006

Troell, M., R. L. Naylor, M. Metian, M. Beveridge, P. H. Tyedmers, C. Folke, K. J. Arrow, S. Barrett, A.-S. Crépin, P. R. Ehrlich, A. Gren, N. Kautsky, S. A. Levin, K. Nyborg, H. Österblom, S. Polasky, M. Scheffer, B. H. Walker, T. Xepapadeas, and A. de Zeeuw. 2014. Does aquaculture add resilience to the global food system? Proceedings of the National Academy of Sciences 111:13257-13263. http://dx.doi.org/10.1073/pnas.1404067111

Turner II, B. L., W. C. Clark, R. W. Kates, J. F. Richards, J. T. Mathews, and W. B. Meyer, editors. 1990. The Earth as transformed by human action: global and regional changes in the biosphere over the past 300 years. Cambridge University Press, Cambridge, UK.

Turner II, B. L., R. E. Kasperson, P. A. Matson, J. J. McCarthy, R. W. Corell, L. Christensen, N. Eckley, J. X. Kasperson, A. Luers, 
M. L. Martello, C. Polsky, A. Pulsipher, and A. Schiller. 2003. A framework for vulnerability analysis in sustainability science. Proceedings of the National Academy of Sciences 100:8074-8079. http://dx.doi.org/10.1073/pnas.1231335100

Van Slyke, D. M. 2007. Agents or stewards: using theory to understand the government-nonprofit social service contracting relationship. Journal of Public Administration Research and Theory 17:157-187. http://dx.doi.org/10.1093/jopart/mul012

Vitousek, P. M., P. R. Ehrlich, A. E. Ehrlich, and P. A. Matson. 1986. Human appropriation of the products of photosynthesis. BioScience 36:368-373. http://dx.doi.org/10.2307/1310258

Vitousek, P. M., H. A. Mooney, J. Lubchenco, and J. M. Melillo. 1997. Human domination of Earth's ecosystems. Science 277:494-499. http://dx.doi.org/10.1126/science.277.5325.494

von Heland, J., and C. Folke. 2014. A social contract with the ancestors: culture and ecosystem services in southern Madagascar. Global Environmental Change 24:251-264. http://dx. doi.org/10.1016/j.gloenvcha.2013.11.003

Walker, B. H., N. Abel, J. M. Anderies, and P. Ryan. 2009. Resilience, adaptability, and transformability in the GoulburnBroken Catchment, Australia. Ecology and Society 14(1):12. [online] URL: http://www.ecologyandsociety.org/vol14/iss1/ $\underline{\operatorname{art} 12 /}$

Walker, B. H., C. S. Holling, S. R. Carpenter, and A. Kinzig. 2004. Resilience, adaptability and transformability in social-ecological systems. Ecology and Society 9(2):5. [online] URL: http://www. ecologyandsociety.org/vol9/iss2/art5/

Waters, C. N., J. Zalasiewicz, C. Summerhayes, A. D. Barnosky, C. Poirier, A. Gałuszka, A. Cearreta, M. Edgeworth, E. C. Ellis, M. Ellis, C. Jeandel, R. Leinfelder, J. R. McNeill, D. deB. Richter, W. Steffen, J. Syvitski, D. Vidas, M. Wagreich, M. Williams, A. Zhisheng, J. Grinevald, E. Odada, N. Oreskes, A. P. Wolfe. 2016. The Anthropocene is functionally and stratigraphically distinct from the Holocene. Science 351(6269). http://dx.doi.org/10.1126/ $\underline{\text { science.aad2622 }}$

Westley, F., P. Olsson, C. Folke, T. Homer-Dixon, H. Vredenburg, D. Loorbach, J. Thompson, M. Nilsson, E. Lambin, J. Sendzimir, B. Banarjee, V. Galaz, and S. van der Leeuw. 2011. Tipping toward sustainability: emerging pathways of transformation. Ambio 40:762-780. http://dx.doi.org/10.1007/s13280-011-0186-9

Williams, M., J. Zalasiewicz, P. K. Haff, C. Schwägerl, A. D. Barnosky, and E. C. Ellis. 2015. The Anthropocene biosphere. Anthropocene Review 2:196-219. http://dx.doi.org/10.1177/2053$\underline{019615591020}$

World Commission on Environment and Development (WCED). 1987. Our common future. Oxford University Press, Oxford, UK.

Worm, B., and R. T. Paine. 2016. Humans as a hyperkeystone species. Trends in Ecology and Evolution 31(8):600-607. http://dx. doi.org/10.1016/j.tree.2016.05.008

Young, O. R., F. Berkhout, G. C. Gallopin, M. A. Janssen, E. Ostrom, and S. van der Leeuw. 2006. The globalization of socioecological systems: an agenda for scientific research. Global Environmental Change 16:304-316. http://dx.doi.org/10.1016/j. gloenvcha.2006.03.004 